症例

\title{
下部食道噴門癌における胸骨縦切開・
}

\section{経縦隔法の経験 と評価}

\author{
東邦大学医学部第 2 外科（主任：竹内節夫教授） \\ 鈴 木 孝雄柴 忠明 寺 嶋 㓮 \\ 橋村千秋 北原信三竹内節夫
}

\section{THE STERNAL SPLITTING.TRANS MEDIASTINAL APPROACH FOR ESOPHAGO-CARDIAC REGION : REPORT OF SIX CASES}

Takao SUZUKI, Tadaaki SHIBA, Takeru TERASHIMA, Chiaki HASHIMURA, Shinzo KITAHARA and Setsuo TAKEUCHI

Second Department of Surgery, Toho University, School of Medicine

(Director : Prof. Setsuo TAKEUCHI)

上腹部正中切開兼胸骨䄳切開・释緃隔法は比較的簡単に，しか子非開胸的に食道胃境 界領域に良好な視野を与える到達法であるという。しかしながら現段階では本法に対す る評価は必ずしも定まったわけではない，そこで著者らも下部食道あるいは噴門部領域 を含んだ癌の 6 例について本法を施行した，その結果本法は食道胃境界領に良好な視野 を与えると思われた。 又, 非開胸的に食道 $\mathrm{Ea}$ 領域を切除する場合には特に有用な到達法 と考兄られた，更に，本法によって食道 $\mathrm{Ei}$ 領域を非開胸的，可視的に処理することが可 能であった。

\section{I 緒 言}

食道胃境界領域への到達法としては，上腹部正中切 開，上腹部正中切開兼左方腹壁横切開あるいは上腹部 正中切開兼左または右開胸法などが用いられている。 しかしながら症例によっては開腹法のみでは充分な視 野が得られなかったり，開胸を避けたい場合もある。 このような場合の対策の一つとして，粟根ら"，江里 ら ${ }^{2 !}$ は上腹部正中切開に胸骨琎切開・経粉隔法を併用 することで比較的簡単に，しかも非開胸的に良好な視 野の得られることを報告している。しかしながら，現 段階では本法に対する評価は必ずしむ定まったわけで はないそそこで著者らむ下部食道あるいは噴門部領域 を含んだ癌の 6 例について上腹部正中切開兼胸骨綎切 開・経綐隔法による到達を試みたので，その経稌を述 べるとともにとの有用性あるいは留意すべき点などに ついて報告する。

\section{II. 胸骨㮆切開・経㮆隔法}

粟根ら゙，汇里らの記載に基ついた。

仰臥位で上腹部正中切開を加え開腹して腹腔内を検 索する，適応を決定した後に皮切を上方に $10 \mathrm{~cm}$ 前後 延長し胸骨を充分に露出する。 そして剣状突起下から 用手的に胸骨裏面と前緹隔結合組織を剩離する。次に 胸骨々膜を電気メスで切開し，更に胸骨下面に腸べラ を挿入した5えで電動鋸で胸骨を維断する，次に胸骨 緥断線の上端で胸骨を横断し，いわゆる $\mathrm{T}$ 字型切開を 完成させる。ここに胸骨用開胸器をかけ開くと，前緹 隔が露出される. 次に肝左葉三角勒帯を切離し, 肝左 葉を右方に翻転した後，心表底部と横隔膜の間を鈍的 に剝離し食道裂孔に達する。剩離した横隔膜を切開し， 心震底部より左右に剶離すると下部食道に対する視野 が得られる.すなわち，上部正中切開の視野と併せる ことにより下部食道および噴門部附近に対する良好な 視野が得られることになる。 


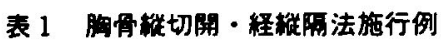

\begin{tabular}{|c|c|c|c|c|c|c|}
\hline No. & 年跉 & 性 & 臭 & 手術名 & 合所应 & 怪過 \\
\hline 1 & 52 & 男 & $\mathrm{CM}^{\text {胃, Borr III }}{ }^{\text {㾔 }}$ & 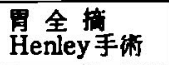 & $(-)$ & $\begin{array}{c}\text { 待後31力月 } \\
\text { 生存中 }\end{array}$ \\
\hline 2 & 49 & 女 & CE, Borr m ${ }^{\text {畋 }}$ & 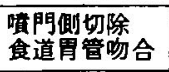 & & $\begin{array}{c}\text { 行後26力月 } \\
\text { 生存中 }\end{array}$ \\
\hline 3 & 60 & 男 & $\begin{array}{c}\text { 畕 } \\
\text { CMAD，Borr IV } \\
\end{array}$ & $\begin{array}{l}\text { 賁全摘 } \\
\text { 窄道吻合 }\end{array}$ & 䋖合不全 & 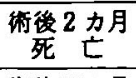 \\
\hline 4 & 51 & 男 & 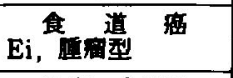 & $\begin{array}{l}\text { 下部蒼道切除 } \\
\text { 食道吻合 } \\
\end{array}$ & 䐔骨々飾炎 & $\begin{array}{l}\text { 行後25力月 } \\
\text { 生存中 }\end{array}$ \\
\hline 5 & 76 & 男 & 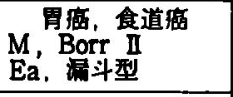 & 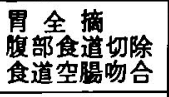 & 維合不刧 & 術後10日 \\
\hline 6 & 57 & 女 & (C) $(\mathrm{E})$, Borr IV & $\begin{array}{l}\text { 残䍚道空䐱 } \\
\text { 昜吻合 }\end{array}$ & 水 & $\begin{array}{c}\text { 術後 3 力月 } \\
\text { 生存中 }\end{array}$ \\
\hline
\end{tabular}

手術終了後の創の閉鎖は横隔膜切開部を綟系結節䋖 合し，前綎隔に portovac カテーテルを㨂入したらえ でステンレスワイヤーで胸骨を閉鎖した，胸部皮切， 腹部創は常法にて閉創した。

\section{III. 症 例}

対象症例は C 領域を含んだ胃癌 4 例， Ea 領域食道 癌兼 $\mathrm{M}$ 領域胃癌 1 例, Ei 領域食道癌 1 例の計 6 例で ある. 以下に各症例を呈示し検討を加える（表 1 ）。

症例 1

52歳, 男性.

胃癌 (CM, Borr III)の診断にて手術を行った，上腹 部正中切開のもとに型の如く胃全摘出を施行したか，

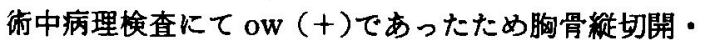

経綎隔法を追加して下部食道に到達し，下部食道を部 分切除するとともに, No.110, 111, 112 リンパ節を郭清 した. 又, 横隔膜の一部も切除した.

本例は術中病理検査の結果, 急遠, 胸骨縦切開・経 檤隔法を併用することで手術を完了することのできた 例である．開胸術を併用せず，そのままの体位で下部 食道に到達し得た点で, 本法の有用性が評価されよう。 本例は㧓後 2 年 7 カ月の現在, 就業している. 本症例 の術前, 術後の胃透視写真を呈示する（写真 1 ）。

症例 2

49歳, 女性.

胃癌 (CE, Borr III) の診断で手術を施行した．本症 例は術前よりX線むよび内視鏡的に Ea への漫潤が

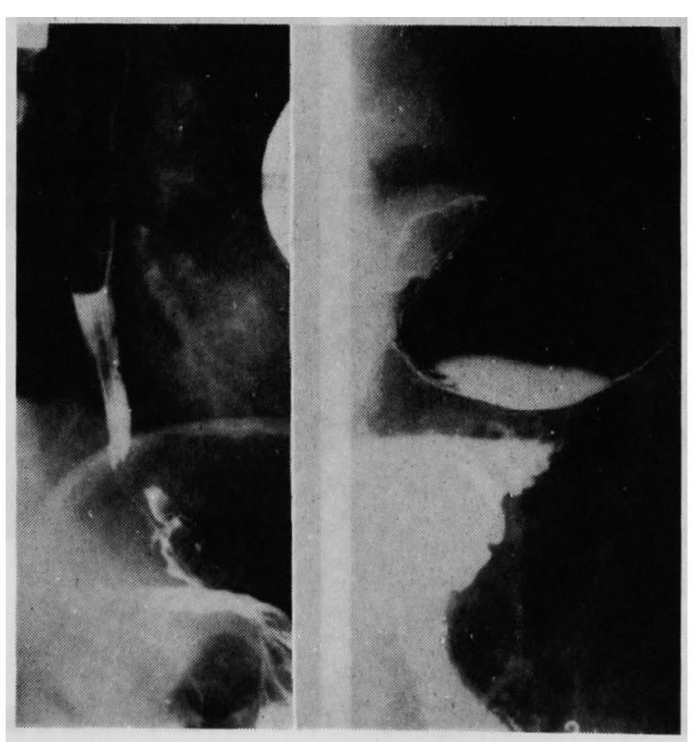

術前

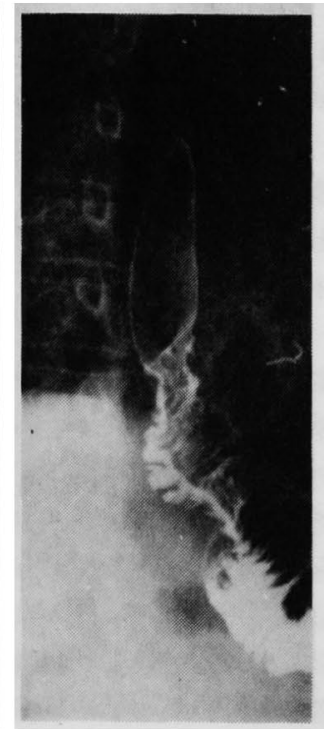

術後

军真1 症例 1 
認められた，そこで上腹部正中切開兼胸骨綎切開・経 糈隔法でフプローチした，下部食道の一部を含めて胃 噴門側切除を行ったう竞で，残胃をるって胃管を形成 し縦隔内で食道胃管吻合を行なわんとした。しかし充 分な視野が得られず，その状況下での手術操作は危険 と考えられた。そこで右開胸し，胸腔内で食道胃管伆 合を行った。

本症例は術前より胸骨綎切開・経縦隔法によるアプ ローチを企画したが，食道切除範囲が Ei の一部に及 び，更に，身長が $140 \mathrm{~cm}$ と短躯であったことなどが本 法によっても充分な視野の得られなかった理由であろ 5. 本症例の術前・術後の胃透視所見を呈示する（写 真 2 ).

\section{症例 3}

60 歳, 男性.

胃癌（CMAD circ, Borr IV)の診断で手術を施行し た. 上腹部正中切開兼胸骨縦切開・経縦隔法でフプロー チし，胃全摘術を完了した，再建は縦隔内で自動吻合 器を用いて食道空腸吻合を行った．手術操作は比較的 容易であった，尚，本症例は縫合不全を来し，第60病 日に死亡した。本症例の術前胃透視所見を呈示する(写 真).

症例 4
51才, 男性.

食道癌 ( $\mathrm{Ei}$, 腫瘤型) の診断で手術を施行した。本症 例は肺結核, 呼吸機能障害を合併しており開胸術は澼 けたいと考えた。そこで上腹部正中切開で腹腔に達し， 腹腔内を検索した後に胸骨縦切開・経綖隔法で下部食 道に到達した。そこで食道病変を直視するとこれを 充分に切除した場合, 当該視野内での吻合操作は困難 と考えられた。 そこで当該術野内で食道病変部を可視 的に処理した後, 頚部に皮切を追加し, 食道を上方抜 去したうえで頝部食道胃管吻合を行った。

本例は胸骨緃切開・経縦隔法によって Ei 領域食道癌 にアプローチしたが，口側に充分な切除線を設定する と，吻合に際して視野の得にくかった一例である.し かし，結果的には非開胸的に手術を終了した。本例は 胸骨々䯑道资を併発した。本例の術前食道胃透視写真を 写真 4 に示す（写龺 4 ）.

症例 5

76 歳, 男性。

食道 (Ea, 漏斗型) と胃 (C, Borr II) の重複瘦の診 断で手術を施行した。高龄，呼吸機能障害などを考虑 して, 開胸は回避す可く上腹部正中切開兼胸骨綎切 開・経縱隔法でフプローチした。食道癌は周囲への骎 潤が著るしく，又，穿孔を来たして周辺に䝢湯を形成

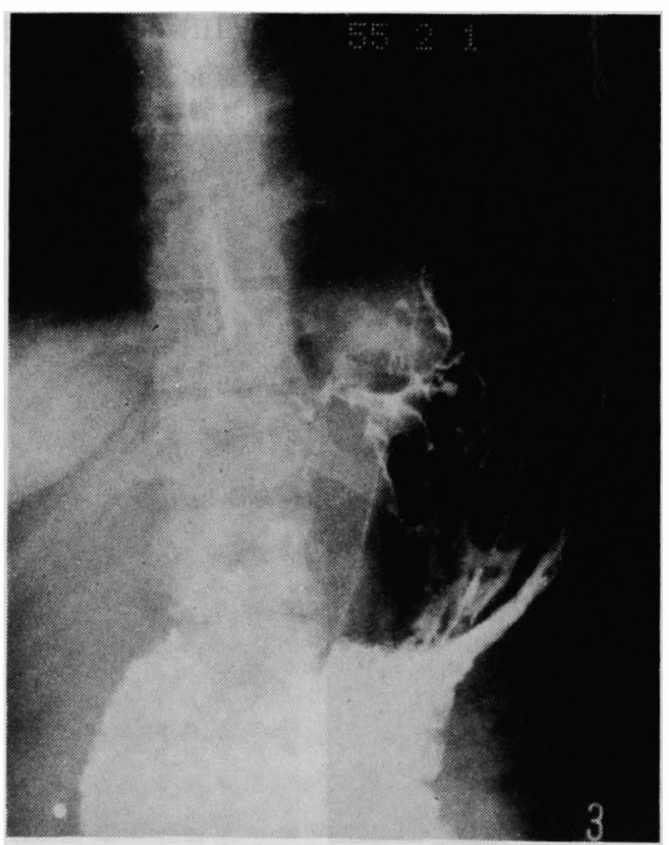

術前

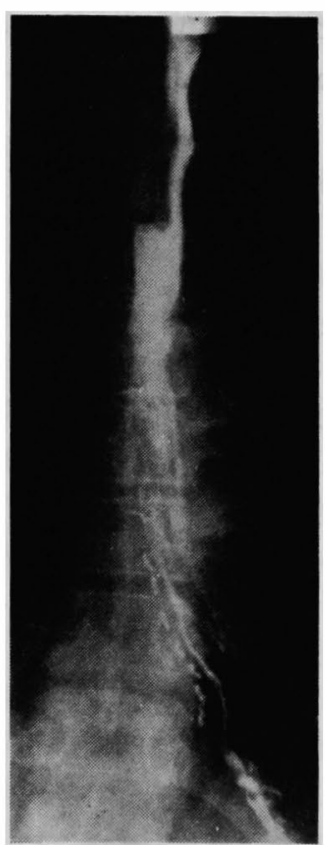

術後

写真 2 症例 2 


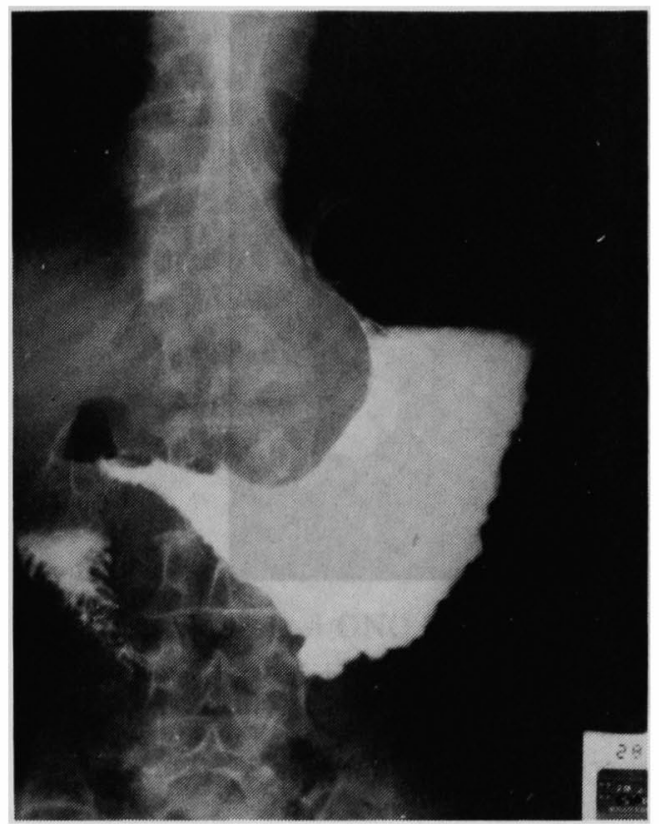

写真 3 症例 3 術前

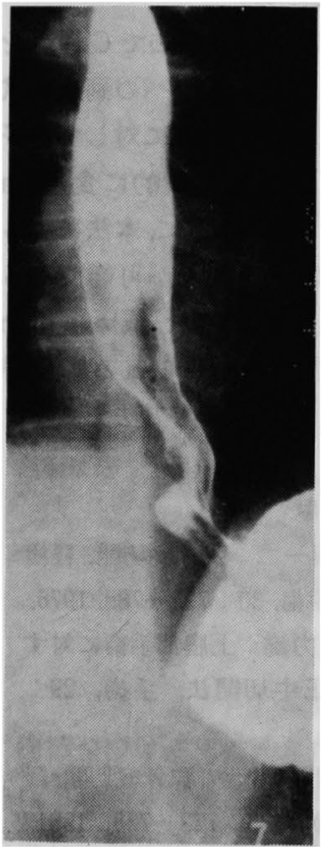

術前

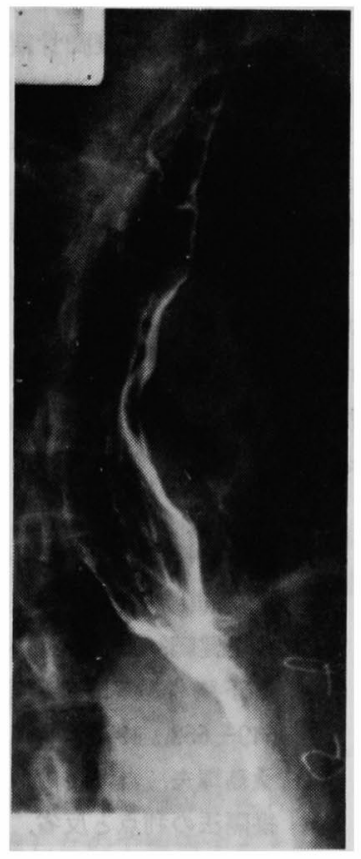

浾後
写真 4 症例 4

していた，腹部食道を含めて胃全摘術を行い，䊮隔内 で食道空腸吻合を行った，本例は縫合不全，膿胸を来 して第10病日に死亡した。本例は本法によって良好な

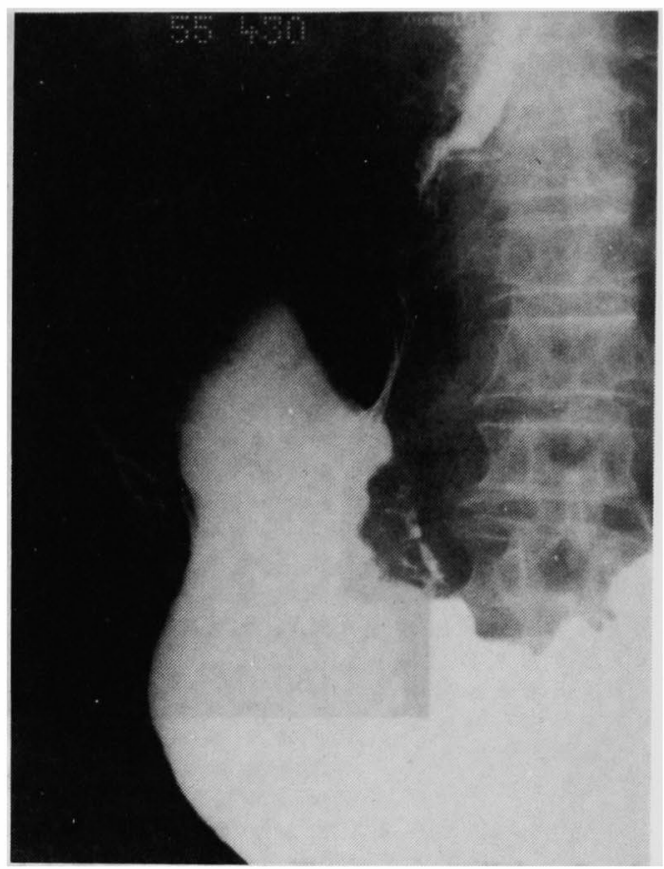

写真 5 症例 5 術前

視野が得られたが，いわゆる污染された手術の状況を 呈したことが合併症に至った原因と考えられる. 本例 の術前食道胃透視写真を示す（写真 5 ).

症例 6

57 歳, 女性.

10年前に胃癌のために胃西全摘，B II 法による再建 を受けている. 残胃癌 ( (C) (E), Borr III) と診断し て手術を施行した。 上腹部正中切開兼胸骨緃切開・経 維隔法でフプローチし, 残胃全摘, 腹部食道切除を施 行したらえで，緥隔内で食道空腸吻合を行った。本例 は術後に左胸膜炎を発症したが良好な経過を辿った。 本例の術前・術後の胃透視写真を示寸（写真 6 ）.

\section{IV. 考 察}

食道胃境界領域へ非開胸的に到達する方法として, 上腹部正中切開または上腹部正中切開兼左方腹壁横切 開が常法されてきた。しかし、これらの切開法のみで は患者の体格, 例えば肥満短躯や肋骨弓角の狭小な場 合などは充分な視野が得られずに手術操作に困難を感 じる場合もあった。このような場合の対策も含めて， 粟根ら”は胸骨綐切開・経緃隔法を提唱し，「1）開胸し ないので侵襲が少ない，2）下部食道をかなりの高さ迄 切除し得る. 3）リンバ節の郭清, 横隔膜の合併切除が 出来る．4）厇い視野で食道空腸吻合が出来る。」と述 


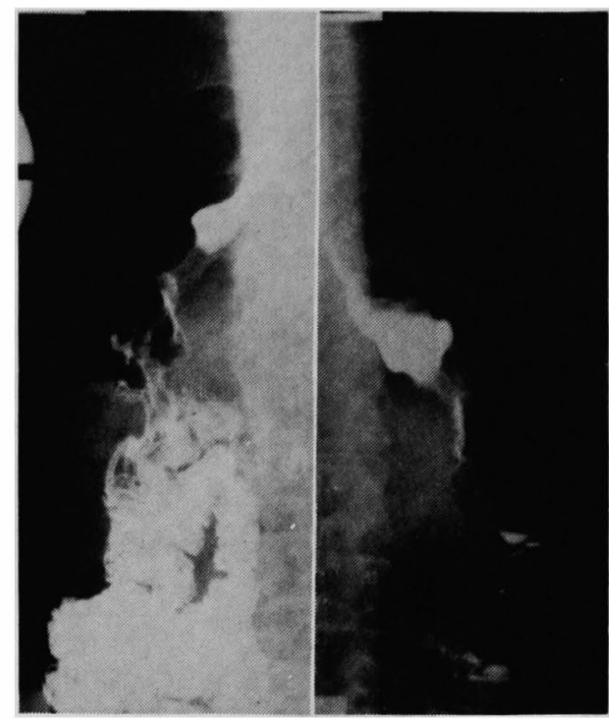

術前

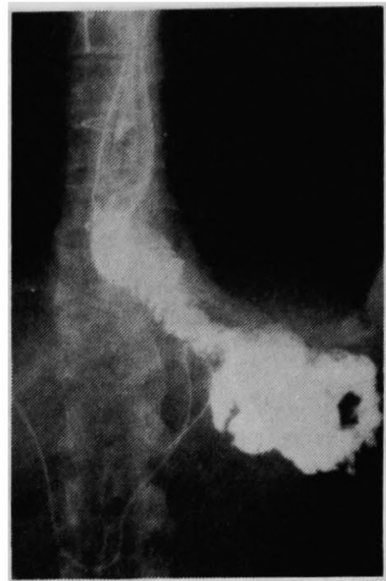

術後

写真 6 症例 6

べている. 本法については既でに若千の評価はある が3)，必ずしも是とするものですない。

症例 1 は本法の利点を最大限に活用し得た症例であ ク，本法の有用性を評価し得る。症例 $2 ， 4$ は本法て アプローチしたむのの充分な視野が得られなかった例 でありこれらは本法の適応の限界を示すものとも考 えられる.すなわち食道病変を適応に入れるとすれば $\mathrm{Ea}$ 領域がその限界であり, Ei 領域については病変自 体は可視的に操作し得てむ，吻合操作に際しては視野 が不充分になることを考虑せねばならない，しかしな がら，たとえ Ei 領域の病変であっても，上方抜去，下 方抜去を併用することで食道病変を可視的に処理し且 つ非開胸的に手術を完了し得ることは大きな利点であ ろら．次に本法に伴う合併症であるが，著者らは表 1 に示したようなさまざまな合併莚を程験した。しかし 症例 3，5の縫合不全は本法に起因するものではない. 今回, 我々が経験した合併症のいつれるは慎重な操作, 充分に無菌的な操作，本法への熟達などで防止し得る と考える。

最後に食道胃境界部癌の根治手術における横隔膜リ ンパ節の郭清の意義は明確化しているわけではない が，その意義は充分に予測し得るところであり4，横隔 膜リンパ節郭清のためには本法は有用な到達法である
と考える.

$$
\text { V.まとめ }
$$

上腹部正中切開兼胸骨緃切開・経縦隔法で C 領域を 含さ胃癌, $\mathrm{Ea}$ 領域食道癌, $\mathrm{Ei}$ 領域食道癌への到達を試 みた. その結果，本法は食道胃境界領域に対して良好 な視野を与支ると思われた、殊に非開胸的に食道 $\mathrm{Ea}$ 領域を切除する場合には有用である.更に, 本法によっ て食道 Ei 領域を可視的に処理することが可能であっ た. 近年とみに増えてきた高令者癌患者, 或いは high riskの患者に対してる開胸法で多くみられる肺合併 症等を受虑することなく積極的に行える方法であると 考古る。

\section{文嗝}

1）粟根康行, 片柳照雄, 伊藤一二：胸骨緃切開, 経横 隔膜的下部食道到達法, 手術, 30：735一788, 1976.

2）江里健輔，守田信義，八牧力雄：上腹部手術に対す る下胸骨分割・上腹部正中切開法, 手術, 29: $649-652,1975$.

3）桑島輝夫, 岩坂尚仁, 芳川博哉他：胸骨槑切開・経 綎隔法の利点と反省, 手術, 35：723-728，1981.

4) 粟根康行, 片柳照雄, 北村正次他胃癌取扱い規約 における問題点一横隔膜リンハ節 (111番) につい て，手術，36:533-538， 1982. 